\title{
5
}

\section{Transforming the banking sector}

\author{
Yiping Huang
}

\section{MASSIVE BURDENS IN THE BANKS}

The health of the Chinese banking system has come under the spotlight since the beginning of the East Asian financial crisis in 1997. In early 1998, the People's Bank of China (PBOC) estimated the average proportion of the non-performing loans (NPLs) at 24 per cent in the four major state-owned commercial banks (SOCBs)the Bank of China (BOC), the Industrial and Commercial Bank of China (ICBC), the Construction Bank of China ( $C B C)$ and the Agricultural Bank of China $(A B C) .{ }^{\text {T This }}$ was much bigger than those of pre-crisis Thailand, South Korea, Indonesia and Malaysia (Huang and Yang 1998). But China maintained strong GDP growth in the following years without major financial instability. ${ }^{2}$

China's entry to the WTO on 11 December 2002 revived anxieties about the sustainability of its banking system. China promised, within five years of joining the WTO, to grant foreign banks market access and to remove geographic and client restrictions. Two years after entry to the WTO, foreign banks will be allowed to do local currency business for Chinese firms, and after five years they will be able to do local retail business. The WTO agreements became effective on 1 February 2002.

Can Chinese banks survive the foreign competition? For some China watchers like Chang (2001), the answer is definitely negative. Others, however, take comfort in the belief that foreign banks will not be able to build branch networks as widespread as those of the domestic banks' within a short period. This is true. What is also true 
is that the SOCBs generate 95 per cent of their profits from about half a dozen coastal cities, including Shenzhen, Guangzhou, Xiamen, Shanghai, Tianjin and Beijing. Unfortunately, these are the battlefields where the foreign banks will come and fight.

There is concern that the banking sector's problems have grown during recent years. Official data, which are based on the recently implemented international loan classification system, show an average NPL ratio in the four SOCBs of around 24 per cent in mid 2003. ${ }^{3}$ This ratio, however, still excludes the 1.4 trillion yuan already transferred to the four Asset Management Companies (AMCs) affiliated to the four SOCBs. Therefore, the NPLs of the whole banking system actually still account for about 35 per cent of total outstanding loans. In 1998, the government injected 270 billion yuan into the four major banks by issuing a special Treasury bond to raise their average capital adequacy ratio (CAR) from 4.6 per cent to above 8 per cent. By the end of 2001, however, the average CAR had come down to around 5 per cent again.

Banking problems represent one of the biggest risks for the Chinese economy now that China has gained entry to the WTO. Whether or not China can escape a financial meltdown depends on how quickly the government can eliminate, or at least contain, the banking problems and improve competitiveness.

\section{BANK MELTDOWN UNLIKELY}

While pessimists often compare China's banking situation to those of pre-crisis countries like Thailand or Mexico, we believe that such comparison ignores some important institutional differences between China and those crisis-affected countries, especially in terms of capital account control and blanket guarantee of deposits.

Given the problems of state-owned enterprises (SOEs) and SOCBs, capital account control is a second-best policy. It reduces efficiency and welfare by restricting domestic enterprises and households' direct access the international capital market. But it also prevents the external speculative attacks that triggered financial crises in some countries. Even if there are problems with some banks, depositors still need to put money into other banks in the country because of restrictions on capital mobility. This ensures that local problems do not lead to systemic disasters. In fact, capital account control was a key factor that enabled China to ride out the storm of the Asian financial crisis in 1998-99 (Huang 2001).

The entry of foreign banks may change the situation. ${ }^{4}$ In March 2002, several foreign bank branches were already receiving US dollar deposits from Chinese 
residents. Of course, full competition from foreign banks is still four years away. In a way, the WTO commitments have served to accelerate banking reforms. In the forseeable future, foreign competition will be mainly in the form of taking wealthy and profitable clients away from local banks (Bonin and Huang 2002). Foreign banks are not likely to build matching networks any time soon. The experiences of other emerging markets suggest that too much foreign competition is not often the major problem. Instead, it is usually too difficult for foreign banks to expand their businesses in the new market. Despite the policy commitments, the Chinese authorities still have plenty of flexibility to restrict foreign competition if domestic banks are not yet ready. A recent example is the new rule introduced by the PBOC that foreign banks' total borrowing from local interbank market cannot exceed 40 per cent of their assets. This rule, while not in violation of the national treatment principle, severely limits

Table 5.1 China committed to open up banking sector after WTO accession

$\begin{array}{ll}\text { Scheduled time } & \text { Expansion of foreign bank businesses } \\ \text { On accession (effective 1 Feb 02) } & \text { Foreign currency business with all companies } \\ & \text { Local currency business with foreign companies } \\ \text { Two years after accession } & \text { Local currency business with all companies } \\ \text { Five years after accession } & \text { Local currencies with all Chinese consumers } \\ & \text { No geographical restriction }\end{array}$

Source: Compiled by Citigroup.

Table 5.2 Estimated contingent liabilities for China, 2002

\begin{tabular}{lcc} 
& & Per cent of \\
& RMB billion & GDP \\
Accumulated public debts & 1,550 & 16.2 \\
Special T-bonds in 1998 for recapitalisation & 270 & 2.8 \\
Estimated costs for bank restructuring & 4,500 & 46.9 \\
Estimated costs for social security funds & 2,500 & 26.1 \\
Municipal government contingent debt & 700 & 7.3 \\
External debts & 1,500 & 15.6 \\
Total & 11,020 & 114.9 \\
\hline
\end{tabular}

Note: This is an updated estimate based on new information available on both gaps in social security funds and municipal government contingent debts for which the central government is guarantor. These were estimated based on discussions with government economists. Source: Citigroup estimates. 
foreign banks' potential in local currency business in the near term and thus shelters the domestic banks from competition pressure.

Another factor that helps keep depositors with the banks is the blanket guarantee of deposits by the state. The guarantee could cause a moral hazard problem if depositors do not discriminate against bad banks. But it maintains the faith of depositors in the shaky state banks. Does the government really have the ability to sustain guarantees? We believe that it has both the fiscal and monetary means to settle bank runs. China's formal public debts accounted for only 17 per cent of GDP at the end of 2002. If we take into account the estimated costs for restructuring banking system and the potential expenditure to finance the pension fund, 47 per cent and 26 per cent of GDP respectively, the contingent liabilities are around 90 per cent of GDP.

This ratio is very high according to any international standards but still does not pose any immediate threat to fiscal sustainability. The Chinese economy has been growing at a remarkable rate, even after adjusting for exaggeration in the official data. Fiscal revenues have been increasing at 15-20 per cent per annum, and fiscal deficits have been kept below 3 per cent of GDP in recent years. But the share of fiscal revenue in GDP is still below 20 per cent and has the potential to rise further. Thus, it should not be difficult for China to absorb the existing contingent liabilities over an extended period. Moreover, the government can also print more money if extra cash is needed to restore confidence in the banking system. Printing money can have adverse macroeconomic impacts, but such impacts are likely to be minimal given the current low inflation.

\section{A COMPREHENSIVE REFORM AGENDA}

The pace of banking reforms accelerated in the wake of the East Asian financial crisis, especially as WTO entry drew closer. From early 2001, policymakers were divided into eight groups exploring various reform options in different areas. The Central Financial Works Conference was held in early February 2002 to put together a blueprint for reform of the financial sector. Although the outcomes of the policy conference were less ambitious than expected, the policy framework for banking reforms encompassing three key areas became clear.

The first area is resolution of existing non-performing loans. The four AMCs will continue to deal with 1.4 trillion yuan of bad loans already transferred from the parent banks. We estimate the overall recovery rate to be 25 per cent at best (Bonin 
and Huang 2001). More worrying are the 3 trillion yuan or more of NPLs still in the banks. The PBOC's current policy is that no more NPLs will be transferred to the AMCs and that the banks should aim to reduce their NPL ratios by $2-3$ percentage points every year over the next five years in order to lower the average NPL ratio to below 15 per cent.

The second area is financial supervision. One of the main decisions at the February policy conference was to create a relatively independent body in charge of financial supervision within the PBOC. This body is expected to introduce international standard bank supervision practices gradually.

The third area is reform of the SOCBs through a three-step approach. Step one continues the reforms to improve internal management systems, including implementation of accounting, auditing and risk assessment systems. These will probably not bring about breakthrough changes but are necessary for the success of the later steps. Step two includes both corporatisation of the banks and introduction of strategic investors. The government intends to introduce a share-holding system in the major banks within two to three years, with the Ministry of Finance (MOF) as the sole owner initially. The MOF will then sell some equity to domestic and foreign strategic investors. Currently, foreign interests are capped at 25 per cent. Finally, step three aims at public listing of the large banks within about five years. The detailed forms of listing still need to be worked out case by case.

Table 5.3 The new policy framework for banking reform

Areas

Resolving the non-performing loans (NPLs)

Bank supervision

Reform of the state-owned commercial banks (SOCBs)
Key measures

The Asset Management Companies (AMCs) continue to absorb the RMB1.4 trillion in NPLs transferred from the four SOCBs The SOCBs are called to lower their NPL ratios by $2-3$ percentage points each year to reach an average of 15 per cent in 2005.

The China Banking Regulatory Commission (CBRC) is separated out from the People's Bank of China (PBOC) to strengthen bank supervision and reform

First step: continue reforms to improve the internal management system. Second step: implement the shareholding system and introduce foreign and domestic strategic investors. Third step: list the banks.

Source: Compiled by Citigroup. 
The dynamism of the reform, rather than the existing program itself, makes us reasonably confident that banking problems can be resolved. Five years ago, privatisation of the SOCBs would not have been acceptable to most policymakers. Today, however, it is already policy that the SOCBs will either be listed or sold soon to foreign strategic investors. China's practical reform approach, popularly characterised as 'crossing the river by groping for the stones', suggests that necessary reform measures will be adopted in order to improve the competitiveness of the banks.

\section{ARE RECENT DECLINES IN NPLS SUSTAINABLE?}

According to official statistics, the average NPL ratio of the four banks has been edging down for the past two years: from 32.9 per cent in December 2000 to 29.9 per cent in December 2001, 28 per cent in June 2002 and 24 per cent in May 2003. This improvement has been impressive, given the extremely negative perceptions of outsiders.

But is this process sustainable? Past successes were mainly attributable to the following factors

- writing off the NPLs using bank profits

- controlling NPLs in newly extended loans

- expanding the outstanding loan base.

Many officials, particularly bank managers, appear to be confident that NPLs should continue to decline for a number of reasons. First, the international standard five-category loan classification system has been implemented through the entire banking system, so bank managers now have a better means to monitor and control credit risks.

Table 5.4 Loan provisioning standards for Chinese banks

Loan category

Special mention

Sub-standard

Doubtful

Loss
Provision requirement

(per cent)

1

25

50

100

Source: People's Bank of China. 
Second, the PBOC system also devised the requirements for loan provisions and demanded that all banks achieve those requirements within three to five years. This system can effectively prevent further build-up of NPLS.

Third, the PBOC granted autonomies to commercial banks that identified and wrote off NPLs. This gave banks almost the same treatment as the AMCs that have so far worked out about one-third of their NPLs with an average recovery rate of 1820 percent.

Fourth, to improve the banks' financial position-and ability to further facilitate workout of the NPLs-the PBOC drafted 'management rules for service-based fee charging of commercial banks'. Currently, fees account for less than 10 per cent of revenues for most Chinese banks. In many other countries, this can be as high as 30-40 per cent.

Fifth, the banks will continue institutional reforms, particularly reform to their ownership structures through shareholding systems, strategic investors or public listings.

While we are encouraged by the past and current changes in the banking sector, we are still not fully convinced that these are sufficient. Banks made limited NPLS in recent years by investing in state-sponsored projects, treasury bonds, and mortgage and consumer loans rapidly. During the past five years, for instance, SOCBs extended about 2 trillion yuan loans to state-sponsored projects. This accounted for about half of the increased loans of that period. The banks also bought a huge amount of government/financial bonds, which now account for about 7 per cent of these banks' total capital utilisation. This does not really represent an improvement in banks' credit culture.

More worrying is the recent pace of credit expansion, at about 20 per cent. From mid 2002, many bank managers were encouraged to extend loans as a way of lowering the NPL ratios. Increasing proportions of the new loans went to the property and automobile industries, which were growing very rapidly. Unfortunately, both of these industries face serious risks of excess capacity. In fact, in mid June 2003, the central bank issued a new policy to restrict lending to the property sector.

\section{THE CASE FOR BREAKING UP THE LARGE BANKS}

We believe that breaking up some of the SOCBs might be a necessary step towards effective reform and transformation. Here we outline five reasons in more detail to support that argument. 
To avoid the 'too big to fail' problem. Although China shares the East Asian characteristic of being 'over-banked' (total bank loans account for 130 per cent of GDP), the individual SOCBs are also too big relative to GDP. The total assets of the Industrial and Commercial Bank of China (ICBC), for instance, were equivalent to 45.3 per cent of China's GDP in 2001. The proportions were slightly lower for the Bank of China (31.4 per cent), China Construction Bank (281 per cent) and the Agricultural Bank of China (25.9 per cent). They were all way above the equivalent proportions for global banks such as Citigroup (6.4 per cent) and Deutsche Bank (5.1 per cent). The relative size of the Chinese banks constitutes not only a financial risk but also a moral hazard ('too big to fail').

The breaking up of the SOCBs, at least the vulnerable ones, could help eliminate this problem. It would be much more feasible, politically and economically, to close down small, inefficient banks than to close a giant bank. More importantly, splitting the big banks into smaller ones could also break down monopolies and promote competition in the banking sector.

To improve the effectiveness of reform. Smaller banks would also mean a shorter chain of information transmission and more effective implementation of policy changes. A counter-argument would be that large banks have the potential to achieve scale efficiencies. But we have already learned from the Chinese experience that scale efficiency does not automatically come with size.

The SOCBs are among the world's largest banks. For instance, ICBC's assets are about half the size of Citigroup's, but its workforce (about half a million) is almost twice as big. The history of central planning has made it even more difficult for SOCBs to implement any policy changes consistently. Breaking up the banks could reduce the level of bureaucracy within them and improve the effectiveness of any reform measures. Increased competition pressure would certainly help promote swifter change.

To help fight the 'liquidity trap'. The essence of China's current 'liquidity trap' is that the banks do not lend, particularly to small and medium-sized private companies. This is partly a reflection of ideological discrimination (bad loans made to the state sector are more justifiable than bad loans made to private companies) and partly due to banks' lack of pricing flexibility (banks cannot charge much higher interest rates for riskier loans extended to small private firms). One problem, however, is that the SOCBs are too big, and large banks across the world basically deal only with large clients. 
Of course, China will need some large banks because it has some large companies. On the whole, however, private small and medium-sized enterprises will probably play a bigger role in China's economic growth in coming years. This is not compatible with the current banking structure, where the four SOCBs account for 70 per cent of total assets. Breaking up the banks would make it easier for them to deal with small and medium-sized companies and enhance financial intermediation.

To help with signing up strategic investors and public listing. The decision to introduce strategic investors into the banks and to list the banks in stock markets was an important policy breakthrough in banking reform. But the feasibility of attracting investors to buy into the SOCBs may be affected by two factors. One, foreign interests are still capped at 25 per cent of equity. This will significantly reduce foreign investors' interest because they will only be minority shareholders. Two, given the size of SOCBs, not many institutions could afford to hold even a small proportion of their equity. The BOC's equity at the end of 2001 was US $\$ 26.3$ billion, therefore a 10 per cent stake-a minority shareholding position-in the BOC would be US $\$ 2.6 \mathrm{bn}$. While some analysts are encouraged by the recent surge of foreign investment in Chinese banks, such as the Bank of Shanghai, Pudong Development Bank and Shenzhen Development Bank, we believe it will be much more difficult to attract investors to the SOCBs in their current form.

Breaking up the SOCBs could improve the banks' quality and affordability for investors, although the 25 per cent cap will remain a constraint. The size of the SOCBs will probably also pose difficulties for public listing, especially if the government aims at listing all the big four.

To smooth the flow of contingent liabilities. The SOCBs have been the main source of China's contingent liabilities. Our estimate of the total cost of restructuring the banking sector is around 46 per cent of GDP - on top of the public debt at 16 per cent of GDP, local government bad debt at 7 per cent of GDP, and pension fund deficits estimated to range between 25-100 per cent of GDP. With a strongly growing economy and steadily rising fiscal revenues, the risk of fiscal crisis is muted as long as the flow of new bad debts is contained.

If the government still attempts to introduce strategic investors to the SOCBs and list them without splitting, the Ministry of Finance will need to clean up the banks' books quickly and take over the bad debts. An instantaneous increase in the debt burden could result in rapid growth in interest payments and weaken investors' 
confidence. Thus the probability of fiscal crisis would rise. If the banks are broken up, however, the government can clean up the banks' balance sheets step by step and streamline the absorption of the contingent liabilities.

\section{RECENT POLICY DEVELOPMENT}

After the leadership transition in late 2002 and early 2003, the government appeared to step up efforts to resolve the banking problems.

The first move was the establishment of the new China Banking Regulatory Commission (CBRC) at the $10^{\text {th }}$ National People's Congress in March 2003, by separating the banking regulatory departments from the PBOC. A well-respected Chinese banker, Liu Mingkang, former president of the BOC, was appointed as the first chairman of the CBRC.

The regulators continue to require the SOCBs to lower their NPL ratios by $2-3$ percentage points each year. Policymakers decided that there would be no further transfer of NPLs to the AMCs. Instead, the regulators would grant necessary policy treatments to the banks in order to facilitate direct identification and writing off of NPLs by banks.

While the commercial banks' aim is still to ve listed publicly at the earliest possible date, policymakers are now more inclined to design different strategies for individual banks. One such proposal is that the ICBC should prepare for listing wholly in the domestic stock market, the BOC should aim at listing wholly overseas, and the $\mathrm{CBC}$ and $\mathrm{ABC}$ should be split up according to either business lines or geographic blocks.

The need for another round of capital injection to these SOCBs is widely recognised among policymakers; the disagreements lie in the size and timing of recapitalisation. Early in 2003, there was much speculation about an expected capital injection of US $\$ 40$ billion, slightly greater than the 1998 capital injection (270 billion yuan). But opponents argued that hasty recapitalisation might cause serious moral hazard, based on experiences of bank restructuring in other countries.

The banking sector is also expected to open the door wider to both foreign and private banks. There is currently a proposal to open five private banks in China, but so far it remains a non-government activity. Policymakers are instead focusing more on introducing foreign banks to the domestic system. The current policy restricting foreign interests in domestic banks to no more than 25 per cent (and 
single investors to no more than 15 per cent) is under review. In other words, foreign investors may be able to acquire higher stakes in Chinese banks in the near future. This may help stimulate foreign investor interest.

Finally, the PBOC is experimenting with interest rate reform in rural credit cooperatives in Guangdong, Guangxi, Hainan and Zhejiang. Interest rates for household and enterprise deposits can be floated upward by a maximum of 50 per cent, while those for all kinds of loans can be floated upward by a maximum of 100 per cent or downward by a maximum of 10 per cent. But the introduction of marketbased interest rates to the wider banking system will probably take years.

\section{NOTES}

1 'China central bank governor on financial situation', People's Daily, March 7, 1998, Beijing.

2 There were several incidents of bank runs in the southwestern and northeastern provinces in 1998 and 1999, but all of them were settled quickly.

3 In our earlier analysis, we noted that the average NPL ratio of the three SOCBS, excluding the $A B C$, was 23 per cent in mid 2002 (Huang 2002). ABC recently reported its NPL data, which was still around 30 per cent in mid 2003. This brought up the average ratio for the four SOCBs.

4 WTO agreements on entry of the foreign banks do not automatically require liberalisation of the capital account, but significant participation of foreign banks in the market does make it more difficult to maintain the control.

\section{REFERENCES}

Chang, G., 2001. The Coming Collapse of China, Random House, New York. Bonin, J.P. and Huang, Y., 2001. 'Dealing with the bad loans of the Chinese banks', Journal of Asian Economics, 12(2):197-214.

Bonin J.P. and Huang, Y., 2002. 'Foreign entry into Chinese banking: does WTO membership threaten domestic banks?', The World Economy, 25(8):1077-93.

Bottelier, P., 2003. Managing China's transition debt: challenges for sustained development, Johns Hopkins University, Baltimore (unpublished).

Hanna, D. and Huang, Y., 2002. 'Bank restructuring in post-crisis Asia', Asian Economic Papers, 1(1):3-42.

Huang, Y., 2001. China's Last Steps Across the River: enterprise and bank reforms, Asia Pacific Press, Canberra.

Huang, Y., 2002. 'Is meltdown of the Chinese banks inevitable?', China Economic Review, 13(4):382-7. 
Huang, Y. and Yang, Y., 1998. 'China's financial fragility and policy responses', AsianPacific Economic Literature, 12(2):1-9.

$\mathrm{Li}, \mathrm{W} ., 2000$. Dealing with Problem Banks in the Context of Bank Restructuring in China, Master Thesis, National Centre for Development Studies, The Australian National University, Canberra.

Lardy, N.R., 1998. China's Unfinished Economic Revolution, Brookings Institution Press, Washington, DC.

$\mathrm{Li}, \mathrm{D} ., 2000$. 'Beating the trap of financial repression in China', Cato Journal, 21(1):7790.

Woo, W.T., 2002.'Some unorthodox thoughts on China's unorthodox financial sector', China Economic Review, 13(4):388-93. 